\author{
Joanna Radwanowicz-Wanczewska \\ University of Bialystok \\ e-mail: j.radwanowicz@uwb.edu.pl \\ ORCID: 0000-0002-2244-7546
}

\title{
IMPLEMENTATION OF NEW EU DIRECTIVES COORDINATING THE PROCEDURES FOR AWARDING PUBLIC CONTRACTS IN EUROPEAN UNION MEMBER STATES: THE EXAMPLE OF POLAND
}

\begin{abstract}
This article concerns the implementation of new EU Directives coordinating the procedures for awarding public contracts in European Union Member States. In a number of countries, including Poland, the process of their implementation (Directive 2014/24/EU of the European Parliament and of the Council of 26 February 2014 on public procurement; Directive 2014/25/EU of the European Parliament and of the Council of 26 February 2014 on procurement by entities operating in the water, energy, transport, and postal services sectors; Directive 2014/23/EU of the European Parliament and of the Council of 26 February 2014 on the award of concession contracts) was delayed. In most cases, the modernization of EU regulations on public procurement required a thorough modification of national regulations in this respect. As a result of the introduction of the package of new Directives, the European Union public procurement market has undergone substantial changes. The need to adjust legal regulations to the changing political, social, and economic situations in a better way has resulted in the transposition of the modernized EU Directives concerning public procurement to the Polish legal system, affecting the final shape of the new Polish Public Procurement Law. The implementation of the package of new Directives has significantly affected the functioning of the Polish public procurement market. For the entities operating in this market, this means the necessity to expand their knowledge, so as to become familiar with the new legal solutions in this respect.
\end{abstract}

Keywords: public procurement, common market, European Union Directives, implementation, Poland.

\section{Introduction}

The functioning of the European Union affects multiple areas and is related to the existence of a large number of legal acts (Nowicki \& Nowicki, 2011: 7). One of the areas subject to special legal regulations is the public 
procurement market. Its size and impact, as well as close links to the European Union common market, mean that it is a major element shaping the legal and economic situation of the entities operating there. The use of public procurement in the European Union serves the purpose of carrying out various policies and implementing political, economic, and social priorities.

In a number of countries, public procurement is a significant element of the gross domestic product (GDP). Broadly understood public entities spend substantial funds on purchasing goods, services, and construction projects. In 2019, the value of the public contracts awarded in Poland amounted to PLN 198.9 billion. This was approx. 8.75\% of Poland's GDP. Of this, in terms of value, $31 \%$ were contracts involving supplies, $36 \%$ were contracts for construction, and $33 \%$ were contracts related to the provision of services. For some time now, the largest group of contracting authorities are local administration authorities (30.74\% in 2019) and their organizational entities (19.11\% in 2019) (Sprawozdanie Prezesa, 2020: 7). Contracts awarded by local government administration involved primarily construction projects (46\% of contracts in 2019) (Sprawozdanie Prezesa, 2020: 31). In this category, the largest sub-group of contracting authorities are municipalities; Poland has 2,477 (302 urban municipalities, including 66 towns and cities having the rights of a district, $642 \mathrm{urban} / \mathrm{rural}$ municipalities, and 1,533 rural municipalities) (Podział administracyjny, n.d.).

However, the value of the purchases made by Polish administration is higher, since the above amount concerns only the contracts subject to the procedures specified in the PPL and does not include the expenses made on the basis of exceptions to the PPL as well as purchases of smaller value that do not exceed the thresholds beyond which the procedures specified in the PPL have to be applied (Krajowy plan, 2017: 3).

\section{Formal legal bases of the system of public contracts in Poland}

For well over a decade now, the normative basis of the system of public contracts in Poland has been the Public Procurement Law of 29 January $2004^{1}$ and the secondary legislation to this Law. ${ }^{2}$ Considering the relatively long period of existence of the PPL, which was adopted in social and economic conditions differing from the existing ones, as well as the numerous amendments made in order to transpose EU Directives and adjust the provisions of the PPL to the changing legal and economic situations, it had become reasonable to draft a new, comprehensive, and cohesive regulation concerning public procurement. In an attempt to meet the needs 
of both public entities and contractors applying to win a public contract, on 11 September 2019, the Sejm (the lower house of the Polish Parliament) adopted a new Public Procurement Law, ${ }^{3}$ which comes into effect on 1 January 2021. Its purpose is to introduce clear and cohesive regulations and solutions based on the efficiency and transparency of public contracts, at the same time taking into account the role of public procurement in shaping state policy in terms of supporting innovation and new technologies through public contracts, as well as the development of small and medium enterprises (Sprawozdanie Prezesa, 2020: 18).

The New PPL takes into account the acts of EU law that had previously been incorporated into the Polish legal system. It also introduces specific solutions awaited by entities operating in the public procurement market, including but not limited to a separate and flexible procedure for awarding public contracts the value of which is below EU thresholds, the possibility of negotiating bids in order to improve them, one court competent to examine complaints, lower court fees, and new rules in terms of indexing the remuneration of the contractor. Another novelty contained in the New PPL is that there are provisions that concern conciliation proceedings available in the event of a dispute occurring in the course of the performance of a public contract of significant value (Sprawozdanie Prezesa, 2020: 18).

In order to prevent an excessive expansion of the New PPL and maintain its clarity, provisions amending other laws have been grouped in a separate legal act together with transitional provisions, adjusting provisions, and repealing provisions necessary to ensure proper functioning of the new regulations on public procurement. The Provisions Introducing the Public Procurement Law were adopted by the Sejm on 11 September 2019.4 These Provisions (with two exceptions ${ }^{5}$ ) come into effect on the same day as the New PPL, i.e. on 1 January 2021.

\section{Implementation of modernized EU Directives concerning public contracts}

The need to revise and modernize the existing legislation involved in the procedure of awarding public contracts in European Union Member States in order to improve the adjustment of legal regulations to the changing political, social, and economic situation has resulted in the implementation of modernized EU Directives on public procurement (Nowe dyrektywy, 2014). On 18 April 2016, the provisions of Directive 2004/18/EC of the European Parliament and of the Council of 31 March 2004 on the coordination of pro- 
cedures for the awarding of public works contracts, public supply contracts and public service contracts ${ }^{6}$ and Directive 2004/17/EC of the European Parliament and of the Council of 31 March 2004 coordinating the procurement procedures of entities operating in the water, energy, transport and postal services sectors ${ }^{7}$ ceased to apply. At the same time, the provisions of Directive 2014/24/EU of the European Parliament and of the Council of 26 February 2014 on public procurement, repealing Directive 2004/18/EC; 8 Directive 2014/25/EU of the European Parliament and of the Council of 26 February 2014 on procurement by entities operating in the water, energy, transport and postal services sectors, repealing Directive 2004/17/EC; 9 and Directive 2014/23/EU of the European Parliament and of the Council of 26 February 2014 on the award of concession contracts ${ }^{10}$ came into effect.

Even though the official deadline for the transposition of the public procurement Directives lapsed on 18 April 2016, their implementation process in European Union Member States had not actually been completed by that date. The reform of the European public procurement law related to the implementation of a package of new Directives on public procurement and concession contracts has covered a number of significant elements of public procurement. As a result, in a number of countries, the implementation of new regulations caused serious problems (EU procurement, 2016). One of the countries where these problems occurred was Poland.

The new regulations were drafted in the spirit of the so-called tool-based approach, i.e. a methodology providing contracting institutions and entities with a sufficiently wide range of tools allowing them to optimally organize the process of awarding contracts. In light of the above, it was mandatory to implement most of the provisions of the new Directives into national legal regulations (Nowe dyrektywy, 2014: 21). In the European Union, the public procurement law is harmonized. However, both the method of actual implementation of EU Directives and the practice in terms of applying legal regulations often differ between the particular Member States. The changes introduced by means of the new regulations are primarily intended to simplify and speed up the process of awarding public contracts (Nowe dyrektywy, 2014: 21). For this reason, they for instance require an obligatory transition to electronic communication between the contractor and the contracting authority and shorten the deadlines for submitting the request for participation and the bids. They also regulate preliminary market consultations and tools such as electronic directories to a greater extent than before. Further, they facilitate the use of the competitive dialog procedure and competitive procedure with negotiations. The new regulations also concern the criteria for evaluating bids. ${ }^{11}$ 
In view of the provisions of the new Directives, applying for the award of a public contract is easier, especially considering the reduced requirements for contractors with respect to documentation and the restriction of the maximum level of requirements as to the economic and financial capabilities of contractors; however, at the same time, more extensive obligations in terms of verifying the situation of contractors have been imposed on contracting authorities (Nowy dyrektywy, 2014: 22-23). Furthermore, taking into account the case law of the European Union Court of Justice, the new regulations specify in more detail a number of issues that previously caused doubts when applied in practice, such as the exclusion of a contractor that has failed to perform a contract or has performed a contract improperly. Another example is Directive 2014/24/EU regulating the issues concerning in-house contracts and public-public cooperation - in this respect, the obligation to use the procedures in terms of awarding public contracts that are specified in the Directive is, on certain conditions, excluded.

It needs to be pointed out that the new regulations include solutions that had already existed in the Polish public procurement system, as well as solutions that were postulated by Poland in the course of negotiations (Nowy dyrektywy, 2014: 22-23). A significant example in this respect is the fact that the Directives require that an entity whose experience and knowledge the contractor relies on does participate in the performance of the contract. Other important elements include adding the competitive dialog procedure to Directive 2014/25/EU (which Poland lobbied for) and creating the possibility of making payments directly to subcontractors, which had already been provided for in the PPL.

The scope of the changes introduced by the new Directives - several examples of which are given above - is very broad. For this reason, their implementation in the Polish legal system required extensive amendments to the PPL. Legislative changes to the law amending the PPL were not completed on time. Due to the delay in the implementation of Directive 2014/24/EU and Directive 2014/25/EU, the Polish Public Procurement Office $(\mathrm{PPO})^{12}$ published a communique concerning their application. In it, the PPO pointed out that with respect to proceedings for the award of a public contract and design contest the value of which does not exceed EU thresholds, if initiated after 18 April 2016, the existing provisions of the PPL applied. In turn, in the case of proceedings for the award of a contract and design contest instigated after that date, in which the value of the contract is equal to or higher than the EU thresholds, the existing provisions of the PPL apply, considering, however, the principle of direct application of the Directives. ${ }^{13}$ 
The relevant amendments to the PPL, implementing the provisions of Directive 2014/24/EU and Directive 2014/25/EU in the Polish legal system, were made by means of the Law of 22 June 2016 amending the Public Procurement Law and Certain Other Laws. ${ }^{14}$ In principle, this Law came into effect on 28 July 2016, with the provisions regulating the use of inhouse contracts coming into effect on 1 January 2017. The amendments to the PPL have eliminated a number of problems the entities awarding public contracts complained about. The resulting extensive changes to the PPL significantly modified the course of proceedings for the award of a public contract. Some of them are outlined here, but a detailed discussion of all of the changes would go beyond the purpose of this article.

The Law amending the PPL did not introduce modifications in terms of the entities obliged to apply the PPL. However, the subject-matter scope of the PPL was changed due to the introduction of new exclusions, as provided for in Directives 2014/24/EU and 2014/25/EU. In addition to the exclusions in terms of application that had already been functioning in the European Union public procurement law and had been implemented to the Polish legal system, new ones were added. They include for instance a change in the scope of the exclusion concerning telecommunications services or a different scope of the exclusion in terms of programs and program materials related to the provision of audio-visual media services or radio media services.

It is also important that the provisions of the implemented Directives promote innovative solutions. For this reason, a new procedure for awarding public contracts, innovative partnership, was added to the PPL. This consists of the contracting authority selecting a contractor or a group of contractors with whom the innovative service or product the contracting authority ultimately wishes to purchase and work together.

The requirement to implement the principle of electronic communication in accordance with the new EU regulations has made a change in the proceedings for the awarding of a public contract; communication between the contracting authority and the contractors is carried out by electronic means. With respect to public works contracts and design contests, Article 22(4) of Directive 2014/24/EU allows Members States to require that specific electronic tools be used. This is implemented by means of a provision of the PPL that allows the contracting authority (in terms of public works contracts and design contests) to require the use of electronic tools for the modelling of construction data and similar tools.

The amendments to the PPL also concern contract notices. Notices exceeding the EU thresholds are sent to the Publications Office of the European Union using the format and the procedures for sending electronic 
notices specified on the website referred to in section 3 of Annex VIII to Directive 2014/24/EU and in section 3 of Annex IX to Directive 2014/25/EU. Notices in the Polish Public Procurement Bulletin are published via electronic means of communication, using the forms available from the web portal of the Office.

According to the PPL, proceedings for the awarding of a public contract are in principle prepared and carried out by the contracting authority. In amending the PPL, a regulation was introduced according to which the contracting authority may entrust ancillary purchasing activities to one of its own organizational entities or to a third party, which in that case acts as its representative. According to the PPL and Article 2(15) of Directive 2014/24/EU, these actions consist of providing support to purchasing activities.

The PPL has also been amended with respect to the central contracting authority. These amendments also concern the possibility of awarding public contracts within a dynamic purchasing system; the requirement to carry out proceedings exclusively with the use of electronic means of communication; allowing contracting authorities to award public contracts covered with a dynamic purchasing system established by a central contracting authority (if this is provided for in the notice of the establishment of the dynamic purchasing system); and the specification of the principles of the contracting authority's liability with respect to the portion of the proceedings it carries out on its own. One of the novelties in the amended PPL is a regulation according to which contracting authorities from various European Union Member States may act together in the process of awarding public contracts.

In terms of the requirements for participation in proceedings, Article 57 of the New PPL provides that the award of a public contract may be applied for by contractors that are not subject to exclusion and meet the conditions for such participation. Currently, the contracting authority may also specify in the contract notice that the award of the public contract may only be applied for by sheltered workshops, social co-operatives, and other contractors who have as their main goal or whose organizationally separate entities (that will carry out the contract) which have as their main goal the social and vocational integration of persons belonging to socially marginalized groups, including but not limited to disabled people, ${ }^{15}$ unemployed people, persons looking for work, non-employed persons, and persons not performing another gainful job; ${ }^{16}$ as well as persons that are being supported in becoming independent; ${ }^{17}$ persons that are imprisoned or have been released from a correctional facility; ${ }^{18}$ persons with mental disorders; ${ }^{19}$ homeless people; ${ }^{20}$ 
persons who have been granted the status of a refugee or supplementary protection in Poland; ${ }^{21}$ persons who are members of a national or ethnic minority and are in an adverse situation; ${ }^{22}$ and persons under the age of 30 and over the age of 50 who have the status of a person looking for work and are not employed. The contracting authority specifies the minimum percentage ratio of employment of the persons belonging to one or more of the above categories, which cannot be lower than $30 \%$ of the personnel of the contractor or his entity that will carry out employment. The above regulations concern the so-called reserved contracts and are intended to improve social and vocational integration of these persons.

The PPL provides criteria that may be used by the contracting authority in order to determine whether contractors are capable of carrying out the contract. Article 24(1) of the PPL specifies situations which should result in the contractor being eliminated from the procedure of awarding a public contract - this is an implementation of all of the conditions the Directives specify as acceptable reasons for the exclusion of the contractor. The PPL also introduces a requirement to exclude contractors that have committed certain types of criminal offenses (those that are particularly harmful to the public interest) or have violated the obligations related to paying taxes, fees, or social or health insurance contributions (Granecki, 2016: 333-334). In the New PPL, the acceptable reasons for exclusion are listed in Article 108. Article 24(5) of the amended PPL (as well as Article 109 of the New PPL) can be seen as a reflection of the conditions specified in Article 57(4) of Directive 2014/24/EU, which are optional reasons for the exclusion of a contractor from proceedings for the awarding of a public contract. If these reasons occur, the contracting authority may exclude the contractor.

Furthermore, in implementing the provisions of Article 57(6) of Directive 2014/24/EU, Articles 24(8)-24(11) of the PPL introduce a novelty: a sanative procedure known as self-cleaning (Granecki, 2016: 333-334). It allows a contractor to participate in the proceedings in spite of there being reasons for exclusion. The contractor is permitted to demonstrate that the measures he has taken are sufficient to prove his reliability. The contractor may for instance demonstrate that he has redressed the damage done through a criminal or fiscal offense or has paid financial compensation for the harm done. If the contracting authority, considering the gravity and the particular circumstances of the contractor's act, decides that the evidence presented by him is sufficient, the contractor is not excluded from proceedings. In the New PPL, the sanative procedure is covered by Articles 110(2) and $110(3)$. 
Furthermore, Article 22d(1) of the PPL now contains a regulation according to which when evaluating the technical or professional capability of the contractor, the contracting authority may specify minimum requirements concerning the education, professional qualifications, experience, and technical potential of the contractor or the persons directed by the contractor to carry out the public contract, which allows for completion of the contract in a manner ensuring high quality. At every stage of the proceedings, the contracting authority may conclude that the contractor does not have the required professional capabilities if engaging the technical or professional resources of the contractor in other business projects may have a negative impact on the completion of the public contract. Regulations allowing the contracting authority to evaluate the contractor's capabilities are also contained in Article 116 of the New PPL.

In order to implement into the Polish legal system, the provisions of Article 56(2) of Directive 2014/24/EU, the amending Law added Article 24aa to the PPL, which concerns the so-called reverse procedure. According to this regulation, in an unrestricted tender, the contracting authority may first evaluate the bids and then investigate whether the contractor whose bid was determined to be the most advantageous is not subject to exclusion and meets the requirements for participation in the proceedings, provided that such a possibility is specified in the terms of reference or in the contract notice (Procedura uregulowana, n.d.). If the contractor evades the execution of the contract or fails to post the required performance bond, the contracting authority may investigate if the contractor is subject to exclusion and if the contractor that submitted the bid that was evaluated as the second most advantageous meets the requirements for participation in the tender. The so-called reverse procedure is also covered by Article 139 of the New PPL.

The PPL also reflects Article 59 of Directive 2014/24/EU, which introduces the European Single Procurement Document. The use of this document is intended to de-formalize the procedure for awarding contracts by means of limiting the number of certificates and other documents submitted by contractors with respect to the reasons for exclusion and the selection criteria (requirements in terms of participation in the proceedings). ${ }^{23}$ According to Article 25a of the amended PPL, a bid or a request for participation submitted by the contractor should be accompanied by an up-to-date representation covering the scope specified by the contracting authority in the contract notice or in the terms of reference. Under Article $25 \mathrm{a}(2)$ of the PPL, if the value of the contract is equal to or greater than the thresholds specified in the provisions published under Article 11(8) 
of the PPL, the contractor makes a representation in the form of the European Single Procurement Document (hereinafter referred to as the "Single Document"). The Single Document is produced using the standard form that is specified in the Commission Implementing Regulation ${ }^{24}$ published under Article 59(2) of Directive 2014/24/EU and Article 80(3) of Directive 2014/25/EU. Pursuant to Article 25a(3) of the PPL, if the contractor cites the resources of other entities in order to demonstrate that there are no reasons for them to be excluded and that the requirements for participation in the tender have been met, he also submits Single Documents with respect to these entities. According to Article 125, the New PPL retains the solutions implemented in terms of the use of the Single Document.

As regards the issue of the procedures for awarding public contracts, innovative partnership is a notable novelty. Beyond that, according to the provisions of Directives 2014/24/EU and 2014/25/EU, the restricted and unrestricted tenders are still of fundamental importance. In the case of unrestricted tenders, the main changes concern making the procedure electronic and modifying the deadlines applicable to these proceedings.

In connection with the changes resulting from the new regulations contained in EU Directives that concern the negotiation procedure with a notice, certain modifications in this respect have been introduced to the PPL, as well (Granecki, 2016: 616-622). Article 55a was also added to the PPL, according to which in the contract notice, the contracting authority specifies the object of the contract, the minimum requirements to be met by all bids, and whether the contracting authority expects to award the contract on the basis of preliminary bids without negotiations or whether negotiations will be divided into stages (in that case, the number of the stages has to be specified, as well). The specification of the object of the contract has to be precise, so as to enable the contractors to determine the nature and scope of the contract and decide whether to submit a request for participation. In the case of the negotiation procedure with a notice, the minimum deadlines are the same as for the restricted tender procedure.

In the case of competitive dialog, the contracting authority may award the contract using this procedure if the circumstances specified in Article 55(1) of the PPL have occurred. This means that competitive dialog may be used in the same cases as the negotiation procedure with a notice. The deadline for submitting requests for participation is the same, i.e. not fewer than 30 days. Furthermore, new elements have been introduced that the contracting authority has to include in the contract notice, i.e. an indicative timeframe of the proceedings and a possibility of dividing the dialog procedure into stages in order to limit the number of solutions. The con- 
tents of the invitation to dialog (Article $60 \mathrm{~d}$ of the PPL) and the invitation to tender (Article 60e(3a) of the PPL) have also been amended. Furthermore, Article $60 \mathrm{f}$ has been added to the PPL, which allows the contracting authority, after selecting the most advantageous bid, in order to confirm financial obligations or other terms of the bid, to negotiate the final terms of the contract with the contractor whose bid has been selected as the most advantageous one, unless this would result in a modification of significant elements of the bid or a change of the needs and requirements specified in the contract notice or would distort competition between contractors or discriminate against them.

In the case of negotiations without a notice, certain amendments concerning the conditions for using this procedure have been introduced (Articles $62(1)(1)$ and $62(1)(3)$ of the PPL). The number of the contractors invited to negotiate has been reduced from five to three. The conditions for awarding single-source contracts under Article 67 of the PPL have also been modified. In turn, in the case of requests for a quotation, there have been no amendments (except for those concerning references to other provisions).

Directive 2014/24/EU provides for a new procedure for awarding contracts: innovation partnership. This is reflected in the PPL where SubChapter 6a ("Innovation Partnership") has been added to Chapter 3 of Division II (Articles 73a-73h). In the amended Law, the actions leading to the establishment of an innovation partnership are specified (Sejm Rzeczypospolitej Polskiej, 2016a). The first of them is the publication of a contract notice in which the contracting authority specifies if it is intending to establish a partnership with one or several partners and presents the criteria for the evaluation of bids. The next action is the submission or requests for participation together with the relevant information. Article $73 \mathrm{~d}$ of the PPL concerns the evaluation of whether the contractors meet the requirements for participation. In carrying out this evaluation, the contracting authority takes into account in particular the capabilities of the contractors in terms of research and development and the design and implementation of innovative products, services, or construction work. Subsequently, the contracting authority invites all (those that are not subject to rejection and meet the eligibility criteria) or some (at least three) of the contractors to submit preliminary bids. According to Article 58 of the PPL, the next steps include negotiations with the contractors who submitted preliminary bids that are not subject to rejection. Then, in line with Article 60 of the PPL, the contracting authority invites the contractors to submit bids. On the basis of these bids, the partner or partners with whom the contracting authority has executed an agreement concerning a public contract the object of which 
is the establishment of an innovation partnership (Article 73g of the PPL) is or are selected. In the new PPL, the solutions concerning innovation partnership are contained in Division III, Chapter 4, Sub-Chapter 2 (Articles 297-299).

In view of the contents of the new Directives, the scope of application of electronic auctions has been expanded in the PPL. Multi-stage auctions have also been introduced. According to Article 91.1 of the Law, in the case of proceedings carried out under the unlimited tender procedure, the limited tender procedure, or the negotiation procedure with a notice, the contracting authority, having evaluated the bids in order to select the most advantageous one, holds an electronic auction - if this was provided for in the contract notice, the invitation to confirm interest, or the notice of establishment of a system of qualifying contractors, if it is possible to precisely define the contents of the terms of reference, and if at least two bids not subject to rejection have been submitted. Article 92.2 allows the contracting authority to hold an electronic auction with respect to contracts awarded under a framework agreement and as part of a dynamic purchasing system. Furthermore, the PPL contains provisions concerning the procedure in the event of a breakdown of the ICT system (Article 91d) and the closing of an auction (Article 91e). The solutions in terms of electronic auctions that have been added to the PPL are specified in Articles 227-238 of the New PPL.

According to the PPL, the criteria for the evaluation of bids are in principle 1) the price or the cost or 2) the price or the cost and other criteria concerning the object of the contract; a non-exhaustive list is contained in Article 91(2). Currently, in terms of specifying bid evaluation criteria, the PPL places emphasis on quality, environmental, and social aspects (Sejm Rzeczypospolitej Polskiej, 2016a). Directives 2014/24/EU and 2014/25/EU allow the Member States to limit the use of the criterion of price or cost as the sole criterion on the basis of which a contract is awarded to certain categories of contracting authorities or to specific types of contracts, which is reflected in Article 91(2a) of the PPL. Article 91(3b) of the PPL is significant, as it provides that life-cycle costing for the object of the contract may be used to specify the cost criterion. If the contracting authority decides to use it, the terms of reference have to outline the information required from contractors and the method of evaluating the costs (Article 91(3d) of the PPL). However, this regulation does not apply to tenders where the object of the contract is covered by the common methodology of life-cycle costing. Article $91(7 \mathrm{~b})$ of the PPL provides that if, under the European Union regulations contained in Annex XIII to Directive 2014/24/EU or 
in Annex XV to Directive 2014/25/EU, the common method of life-cycle costing is obligatory, and this method applies to evaluating these costs. Analogous provisions are contained in Article 245 of the New PPL.

Article 69 of Directive 2014/24/EU concerns the obligation of contracting authorities to require that contractors provide explanations regarding the price or costs proposed in the bid where the bid appears to be abnormally low in relation to the relevant construction work, supplies, or services. This regulation is reflected in the amended PPL. According to Article 90(1), if the price or cost offered or a significant constitutive element thereof seems abnormally low in relation to the object of the contract and raises doubts on the part of the contracting authority as to the whether this object will be carried out in accordance with the requirements specified by the contracting authority or in accordance with the requirements following from separate legal regulations, the contracting authority requests explanations, which include in the form of evidence regarding the calculations of the price or the cost. An analogous regulation is contained in Article 224 of the New PPL.

Article 89 of the PPL has been amended in terms of the reasons for bid rejection. These reasons have been specified on the basis of the definition of irregular and unacceptable bids contained in Article 26 of Directive 2014/24/EU. According to Article 90(3) of the PPL (and Article 224(6) of the New PPL), the contracting authority rejects a bid if the contractor has failed to provide explanations or if the evaluation of the explanations, including the evidence submitted, confirms that the bid contains an abnormally low price or cost in view of the object of the contract. The Law also lists the cases where a bid cannot be rejected.

Article 99 of the PPL concerns framework agreements. Amendments to the Law include changes related to the implementation of Directive 2014/24/EU in this respect (Granecki, 2016: 969-972). First of all, executing framework agreements is now possible across a wider spectrum. The contracting authority may execute them after completing proceedings not only under the unlimited or limited tender procedure or the negotiation procedure with a notice, but also under the competitive dialog procedure or the innovation partnership procedure. The principles of awarding contracts to a contractor with whom the contracting authority has executed a framework agreement have also been modified (Article 101a (1) of the PPL). When awarding a public contract under a framework agreement, the contracting authority may not make material changes to the terms and conditions of the contract specified in the framework agreement (Article 101a (3) of the PPL). In the New PPL, framework agreements are covered by Articles 311-315 among others. 
A dynamic purchasing system is a concept that has been introduced to the Polish public procurement system as a transposition of the provisions of the EU Directives. Amendments to the PPL have simplified dynamic purchasing systems, which are electronic processes, limited in time, for awarding public contracts the object of which are generally available services, supplies, or construction work. Like Directive 2014/24/EU, the amended PPL provides that the contracting authority may establish a dynamic purchasing system and use it to award contracts covered with the system on the basis of the provisions concerning the awarding of contracts under the limited tender procedure, which apply accordingly (unless Articles $102-104 \mathrm{~g}$ of the PPL provide otherwise). A dynamic purchasing system may be divided into categories of supplies, services, or construction work, which are defined on the basis of the features of the contracts to be awarded within the specific category. The legal solutions concerning dynamic purchasing systems added to the amended PPL are also present in the New PPL (Articles 316-324).

Regulations concerning contracts in the areas of defence and security are contained in Articles 131a-131w of the PPL (and in Articles 395-430 of the New PPL). These provisions are related to the implementation of Directive 2009/81/EC of the European Parliament and of the Council of 13 July 2009 on the coordination of procedures for the award of certain work contracts, supply contracts and service contracts by contracting authorities or entities in the fields of defence and security, and amending Directives 2004/17/EC and 2004/18/EC. ${ }^{25}$

The amendments to the PPL have also introduced certain changes to the sector procedure. The modifications to Article 132 of the PPL, which specifies the scope of application of regulations concerning the sector procedure, have resulted in the obsolescence of these regulations e.g. to operations consisting in searching for oil and gas. The scope of the postal services covered with sector regulations has also been changed. Pursuant to Article 134(1) of the PPL, the contracting authority may award a sector contract under the unlimited tender procedure, the limited tender procedure, the negotiation procedure with a notice, the competitive dialog procedure, the negotiation procedure without a notice, the sole source procedure, and the innovation partnership procedure. The same solution has been adopted in Article 376 of the New PPL. According to the provisions of both these Laws, a contracting authority operating in the given sector may also execute a framework agreement. Contracting authorities operating in the given sector may also use dynamic purchasing systems, electronic catalogues, electronic auctions, centralized purchasing activities, and joint procurement. 
The amendments have introduced the concept of social services to the PPL. These services include e.g. some of the health, educational, cultural, hotel, restaurant, and legal services. In the case of sector contracts, the threshold for applying the provisions of the PPL to these types of services is EUR 1,000,000. The contracts for social services concern the services listed in Annex XIV to Directive 2014/24/EU and in Annex XVII to Directive 2014/25/EU. The amended PPL regulates the proceedings for the award of a public contract concerning social services. The contracting authority specifies the method of carrying out these proceedings. In this respect, the contracting authority is obliged to comply with the procedural framework following from the PPL (Wójcik, 2016).

Amendments to the PPL also include modifications related to agreements concerning public contracts. The Law now specifies the circumstances in which the arrangements made in an agreement concerning a public contract or in a framework agreement may be changed. The circumstances listed in the PPL are a reflection of Article 73 of Directive 2014/24/EU.

It should be added that the new package of public procurement Directives is supplemented with Directive 2014/23/EU of the European Parliament and of the Council of 26 February 2014 on the award of concession contracts. This Directive outlines the legal framework for granting concession contracts, at the same time guaranteeing that contractors in the European Union have actual and non-discriminatory access to the EU market and enjoy higher legal certainty with respect to the legal regulations in force. Directive 2014/23/EU contains a number of solutions that are identical or analogous to those contained in Directives 2014/24/EU and 2014/25/EU, as discussed above. However, in comparison to them, it provides for more freedom in terms of granting concession contracts (Przeszło, 2015: 82). The deadline for the implementation of Directive 2014/23/EU (18 April 2016) was not observed by Poland. On 14 December 2016, the Law of 29 November 2016 on Concession Contracts Concerning Construction Works and Services, ${ }^{26}$ which is intended primarily to implement Directive $2014 / 23 / \mathrm{EU}$ in the Polish legal system and replace the Law of 9 January 2009 on Concessions Concerning Construction Works and Services. ${ }^{27}$

The amendments introduced by the new Law include terminology among others (Prętnicki, 2016). According to Article 2 of the LCCCCWS, the entity obliged to apply the provisions of this Law is the contracting authority, whereas previously it was the concession contract grantor. The contracting authority has been defined by means of a reference to the provisions of the PPL. In the new regulation, the concepts defining the participants of the proceedings for the execution of a concession contract (at various stages), 
i.e. an interested entity, a candidate, and a bidder, have been replaced with the concept of a contractor. According to Article 2 of the LCCCWS, the contractor is a natural person, a legal person, or an organization without legal personality or a group of such entities that apply for the award of a concession contract or have submitted a bid. The introduction of new terminology is justified with the provisions of the procurement Directives and the changes regarding the permitted courses of the proceedings for the award of a concession contract (Article 29 of the LCCCWS).

The scope of the entities to which the regulations concerning the award of a concession contract for construction work or services apply has been expanded, since the definition of a contracting authority, as contained in Article 2(11) of the LCCCWS, covers the entities referred to in Article 3(1)(1) of the PPL (i.e. the entities operating in the public finance sector, as defined in public finance regulations). The scope of the contracting authorities to which the provisions of the new Law apply has been expanded compared to the previous regulation, especially that contracting authorities operating in specific sectors are also obliged to comply with the LCCCWS.

The provisions of the new Law apply to concession contracts the estimated value of which is equal to or higher than the PLN equivalent of EUR 30,000 , which is in line with the threshold specified in the PPL. The catalogue of exclusions is similar to the one provided for in the PPL. For instance, concession contracts concerning specific legal services (Article 5(1)(3)(f) of the LCCCWS) and the acquisition of ownership or other rights to existing buildings and properties (Article 5(1)(3)(c) of the LCCCWS) are not covered by the scope of the application of the new Law. The Polish legislature has narrowed down the catalogue of exclusions provided for in Directive $2014 / 23 /$ EU by not excluding agreements executed in the water and sewage sector and the public transport sector from the scope of application of the LCCCWS. The adopted solution is justified by the fact that these sectors enjoy the interest of contracting authorities and leaving these agreements in the catalogue of exclusions would have a negative impact on the market of concession contracts in Poland (Sejm Rzeczypospolitej Polskiej, 2016b).

In Articles 3(3)-3(5), the LCCCWS implements in the Polish legal system the EU regulations concerning the transfer by a concessionaire of the economic risks related to the operation of building structures or the provision of services, including the risks related to supply and demand.

Furthermore, the LCCCWS contains provisions concerning the assessment of the value of concession contracts for construction work or services by means of comparing this value to the total revenue of the concessionaire achieved over the term of the contract (excluding VAT), to be evaluated 
by the contracting authority with due diligence, on account of the remuneration for the completion of the construction work or the provision of services and the management of these services (i.e. the services being the object of the concession), increased by the value of the supplies and services accompanying these services or work (Article 6(1) of the LCCCWS). Under the new regulations, the contracting authority estimates the value of the concession contract using an objective method, as specified in concession contract documents (Article 6(4) of the LCCCWS).

The new Law also contains a regulation concerning mixed concessions that cover various types of concession contracts (construction works, services, social services, and other special services) at the same time, and contracts awarded under various legal frameworks, i.e. covering both concession contracts and classic or sector contracts. The Law also provides for the need to identify and eliminate conflicts of interest. This is to be achieved by Article 30 of the LCCCWS and several of the reasons for excluding a contractor from proceedings that are listed in Article 32 of the LCCCWS.

Pursuant to Article 12 of the LCCCWS, a contracting authority preparing and carrying out proceedings for the award of a concession contract is obliged to comply with the principles of fair competition and equal treatment of contractors, as well as the principles of proportionality and transparency. The contracting authority may not prepare and carry out these proceedings in a manner intended to evade the application of the LCCCWS. The principle of open nature of concession-awarding proceedings, which was in force under the previous regulations, has been replaced with the principle of transparency of concession-awarding proceedings, which requires information related to the proceedings to be provided only in the cases specified in the Law (Article 13 of the LCCCWS) (Sejm Rzeczypospolitej Polskiej, 2016b).

The amendments made to the LCCCWS also concern the principles of publishing a notice of instigation of proceedings for the award of a concession contract, including but not limited to the place of publication, the use of standard forms, the exceptions to the obligation to publish a concession contract notice, and the permissibility of publishing a notice of an intention to award a concession contract.

Articles 29(1)-29(3) of the LCCCWS contain a new regulation concerning the course of the proceedings for the award of a concession contract. The obliged party organizes these proceedings in a manner corresponding to its needs. The new Law has introduced changes in terms of the eligibility criteria, the required and optional reasons for exclusion from proceedings for the award of a concession contract, and the bid's evaluation criteria. 
In order to provide more market participants with access to concession contracts, the Law limits the term for which they may be awarded. According to Article 45 of the LCCCWS, a concession contract may be awarded only for a fixed term. Concession contracts are usually longterm contracts. In the case of concession contracts awarded for a term of more than five years, according to Article 18 and recital 52 of Directive 2014/23/EU, this term cannot exceed the period during which the concessionaire may reasonably expect to recoup the investments made in order to complete the construction work or the provision of services, together with a return on the invested capital, considering the initial investments and the investments made during the duration of the concession. Like in Directive 2014/23/EU, in the new Law, the principles concerning amendments to concession contracts have been specified in more detail. The catalogue of cases where a concession contract may be amended has also been expanded.

In the LCCCWS, the use of legal protection measures in proceedings concerning the awarding of a concession contract have been regulated analogously to the use of the measures available with respect to public procurement. Pursuant to Article 53 of the LCCCWS, the authority competent to examine the appeals made in the course of the proceedings for the award of a concession contract is the Polish National Appeal Board. According to Article 56 of the LCCWS, the parties to appeal proceedings may file, with the relevant court, a complaint against the ruling or decision that concludes appeal proceedings.

\section{Conclusions}

In conclusion, it should be pointed out that the modernization of legal regulations on public procurement required, in most cases, a thorough modification of national regulations in this respect. As a result of the introduction of the package of new Directives, the European Union public procurement market has undergone substantial changes. The process of their implementation was delayed in a number of countries, including Poland. In some countries, a solution consisting in adopting a completely new law on public procurement was used. In turn, in the countries where the existing regulations were only amended, there have been problems with full implementation of the Directives (EU procurement, 2016). The implementation of the package of new Directives has significantly affected the functioning of the Polish public procurement market. For the entities operat- 
ing in this market, this means the necessity to expand their knowledge, so as to become familiar with the new legal solutions concerning public procurement.

\section{N O T E S}

1 Ustawa - Prawo zamówień publicznych z dnia 29 stycznia 2004 r. Dz. U. z 2019 r., poz. 1843, ze zm. (hereinafter referred to as the "PPL").

2 However, when the provisions of the PPL are applied, the principles of spending funds by entities belonging to the public finance sector, as established in the Law of 27 August 2009 on Public Finance (Ustawa o finansach publicznych z dnia 27 sierpnia 2009 r. Dz. U. z 2019 r., poz. 869, ze zm.), are also taken into account. To the extent the actions taken by the contracting authority and the contractors in proceedings for the award of a public contract that are not regulated in the PPL, the provisions of the Civil Code of 23 April 1964 (Ustawa - Kodeks cywilny z dnia 17 listopada 1964 r. Dz. U. z 2019 r., poz. 1145, ze zm.) apply. Furthermore, in proceedings pending as a result of a complaint filed with a court, the provisions of the Code of Civil Procedure of 17 November 1964 (Ustawa Kodeks postępowania cywilnego z dnia 17 listopada 1964 r. Dz. U. z 2020 r., poz. 1575, ze zm.) concerning appeals apply, unless statutory regulations provide otherwise.

${ }^{3}$ Ustawa - Prawo zamówień publicznych z dnia 11 września 2019 r. Dz. U. z 2019 r., poz. 2019, ze zm. (hereinafter referred to as the "New PPL").

4 Ustawa - Przepisy wprowadzające ustawę - Prawo zamówień publicznych z dnia 11 września 2019 r. Dz. U. z 2019 r., poz. 2020, ze zm.

5 Article 85.5 of the Provisions came into effect 14 days after its publication and Article 88 of the Provisions - on 1 March 2020.

${ }^{6}$ Directive 2004/18/EC of the European Parliament and of the Council of 31 March 2004 on the coordination of procedures for the award of public works contracts, public supply contracts and public service contracts. OJ L 134 of 30.4.2004, p. 114.

7 Directive 2004/17/EC of the European Parliament and of the Council of 31 March 2004 coordinating the procurement procedures of entities operating in the water, energy, transport and postal services sectors. OJ L 134 of 30.4.2004, p. 1.

8 Directive 2014/24/EU of the European Parliament and of the Council of 26 February 2014 on public procurement, repealing Directive 2004/18/EC. OJ L 94 of 28.3.2014, p. 65, as amended.

9 Directive 2014/25/EU of the European Parliament and of the Council of 26 February 2014 on procurement by entities operating in the water, energy, transport and postal services sectors, repealing Directive 2004/17/EC. OJ L 94 of 28.3.2014, p. 243, as amended.

10 Directive 2014/23/EU of the European Parliament and of the Council of 26 February 2014 on the award of concession contracts. OJ L 94 of 28.3.2014, p. 1.

11 Importantly, even though the Directives introduce specific modifications, promoting the use of criteria other than the price and placing emphasis on the possibility of taking into account the costs of a product's life cycle, the price may still be the sole criterion used by the contracting authority, unless this possibility is limited by the Member State (Olejarz, 2014: 9).

12 The Polish Public Procurement Office is a budgetary entity established to provide services to the President of the Public Procurement Office, who is a central authority within government administration that is competent with respect to cases concerning public procurement, to the extent specified in the PPL. 


\section{Joanna Radwanowicz-Wanczewska}

13 If proceedings for the award of a public contract or a design contest are instigated and the value of the contract is equal to or higher than the EU thresholds, the communique contains proposals for contracting authorities in terms of specific actions (to be taken until the above Directives have been transposed to national law) concerning the preparation and carrying out of proceedings for the award of a public contract, modifications to agreements, the conditions for applying the PPL, and the publication of announcements (Komunikat dotyczący, n.d.).

14 Ustawa o zmianie ustawy - prawo zamówień publicznych z dnia 22 czerwca $2016 \mathrm{r}$. Dz. U. z 2016 r., poz. 1020, ze zm.

15 This regulation concern the disabled, as defined in the Law of 27 August 1997 on Vocational and Social Rehabilitation and on the Employment of the Disabled (Ustawa o rehabilitacji zawodowej i społecznej oraz zatrudnianiu osób niepełnosprawnych z dnia 27 sierpnia 1997 r. Dz. U. z 2020 r., poz. 426, ze zm.).

16 This concerns the unemployed, persons looking for work, non-employed persons, and persons not performing another gainful job, as defined in the Law of 20 April 2004 on the Promotion of Employment and the Institutions of the Labor Market (Ustawa o promocji zatrudnienia i instytucjach rynku pracy z dnia 20 kwietnia 2004 r. Dz. U. z 2020 r., poz. 1409 , ze zm.).

17 Persons that are being supported in becoming independent are specified in Articles 140(1) and 140(2) of the Law of 9 June 2011 on Supporting Families and on the System of Replacement Custody (Ustawa o wspieraniu rodziny i systemie pieczy zastępczej z dnia 9 czerwca 2011 r. Dz. U. z 2020 r., poz. 821).

18 This concerns persons that are imprisoned or have been released from a correctional facility, as referred to in the Criminal Executive Code of 6 June 1997 (Ustawa - Kodeks karny wykonawczy. Dz. U. z 2020 r., poz. 523, ze zm.), who have problems with integrating into society.

19 This concerns persons with mental disorders, as defined in the Law of 19 August 1994 on the Protection of Mental Health (Ustawa o ochronie zdrowia psychicznego z dnia 19 sierpnia 1994 r. Dz. U. z 2020 r., poz. 685).

20 This concerns the homeless, as defined in the Law of 12 March 2004 on Social Assistance (Ustawa o pomocy społecznej z dnia 12 marca 2004 r. Dz. U. z 2020 r., poz. 1876).

21 This concerns the persons who have been granted the status of a refugee or supplementary protection in Poland, as referred to in the Law of 13 June 2003 on Providing Protection to Foreigners in the Republic of Poland (Ustawa o udzielaniu cudzoziemcom ochrony na terytorium Rzeczypospolitej Polskiej z dnia 13 czerwca 2003 r. Dz. U. z 2019 r., poz. 1666, ze zm.).

22 This concerns in particular persons who are members of a national or ethnic minority, as defined in the Law of 6 January 2005 on National and Ethnic Minorities and on Regional Languages (Ustawa z dnia 6 stycznia 2005 r. o mniejszościach narodowych i etnicznych oraz o języku regionalnym. Dz. U. z 2017 r., poz. 823).

23 This regulation is related to recital 84 of the preamble to Directive 2014/24/EU, in which it is pointed out that many contractors find that one of the major obstacles to their participation in public procurement consists of administrative burdens deriving from the need to produce a substantial number of certificates or other documents.

${ }^{24}$ Commission Implementing Regulation (EU) 2016/7 of 5 January 2016 establishing the standard form for the European Single Procurement Document. OJ L 3 of 6.1.2016, p. 16 . 
25 Directive 2009/81/EC of the European Parliament and of the Council of 13 July 2009 on the coordination of procedures for the award of certain works contracts, supply contracts and service contracts by contracting authorities or entities in the fields of defense and security, and amending Directives 2004/17/EC and 2004/18/EC. OJ L 216 of 20.8.2009, p. 76 .

26 Ustawa o umowie koncesji na roboty budowlane lub usługi z dnia 29 listopada $2016 \mathrm{r}$. Dz. U. z 2016 r., poz. 1920 (hereinafter referred to as the "LCCCCWS"). Articles 20(1)(4)20(1)(7), 20(3)-20(5), and 50 of this Law (concerning in-house contracts and publicprivate partnership) came into effect on 1 January 2017.

27 Ustawa o koncesji na roboty budowlane i usługi z dnia 9 stycznia 2009 r. Dz. U. z 2016 r., poz. 113.

\section{R E F E R E N C E S}

Czarnecka, J., Kowalski, A., Olejarz, M., Ołdak-Bułanowska, K., Pożarowska, J., Pyziak, W., Wosiecka, M. (2014). Zamówienia publiczne w Unii Europejskiej po modernizacji - nowe unijne dyrektywy koordynujace procedury udzielania zamówień publicznych. Warsaw: Urząd Zamówień Publicznych.

EU procurement reform guide 2016. (2016). Retrieved from http://bpcc.org.pl/ uploads/ckeditor/attachments/10342/EU_Public_Procurement_Reform_ Guide_Wierzbowski_Eversheds_2016.pdf

Granecki, P. (2016). Prawo zamówień publicznych. Komentarz. Warsaw: C.H. Beck.

Komunikat dotyczący obowiązywania dyrektywy 2014/24/UE oraz dyrektywy 2014/25/UE z dnia 26 lutego 2014 roku. (n.d.). Retrieved from https://www. uzp.gov.pl/aktualnosci/archiwalne/test.

Nowe dyrektywy w sprawie zamówień publicznych i koncesji zostały przyjęte przez Parlament Europejski i Rade. (2014) [PDF file]. Informator UZP, 2-3/2014. Retrieved from https://www.uzp.gov.pl/baza-wiedzy/publikacje/informatory -uzp.

Nowicki, H., Nowicki, P. (2011). Zamówienia publiczne w wybranych państwach Unii Europejskiej. Warsaw: Polska Agencja Rozwoju Przedsiębiorczości.

Podział administracyjny Polski (n.d.). Główny Urząd Statystyczny. Retrieved from https://stat.gov.pl/statystyka-regionalna/jednostki-terytorialne/podzialadministracyjny-polski.

Prętnicki, M. (2016). Zmiany w umowach koncesji od 14 grudnia 2016 r. Prawo dla Samorządu. Retrieved from https://prawodlasamorzadu.pl/2016-12-06zmiany-w-umowach-koncesji-od-14-grudnia-2016-r.

Procedura uregulowana w art. 24aa ustawy Pzp, tzw. "procedura odwrócona". (n.d.). Retrieved from https://www.uzp.gov.pl/baza-wiedzy/interpretacjaprzepisow/pytania-i-odpowiedzi-dotyczace-nowelizacji-ustawy-prawo-zamo wien-publicznych/procedura-uregulowana-w-art.-24aa-ustawy-pzp,-tzw.procedura-odwrocona. 
Przeszło, E. (2015). Zamówienia publiczne w świetle nowych dyrektyw unijnych. Przegląd Naukowy Disputatio, XIX, 1, 2015, 73-84.

Sejm Rzeczypospolitej Polskiej. (2016a). Uzasadnienie do projektu ustawy o zmianie ustawy Prawo zamówień publicznych $i$ niektórych innych ustaw. Druk nr 366.

Sejm Rzeczypospolitej Polskiej. (2016b). Uzasadnienie projektu ustawy o umowach koncesji na roboty budowlane lub ustugi. Druk nr 612.

Sprawozdanie Prezesa Urzędu Zamówień Publicznych o funkcjonowaniu systemu zamówień publicznych w 2019 r. (2020). Warsaw: Urząd Zamówień Publicznych.

Urząd Zamówień Publicznych. (2017). Krajowy plan działań w zakresie zrównoważonych zamówień publicznych na lata 2017-2020. Warsaw: Urząd Zamówień Publicznych.

Wójcik, P. (2016). Zamówienia społeczne w świetle nowej dyrektywy. Prawo.pl. Retrieved from https://www.prawo.pl/samorzad/zamowienia-spoleczne-wswietle-nowej-dyrektywy,232196.html. 